\title{
Immune response from STRIDE, a randomized, Phase II, open-label study of sipuleucel-T (sip-T) with concurrent vs sequential enzalutamide (enz) administration in metastatic castration-resistant prostate cancer (mCRPC)
}

\author{
Charles G Drake ${ }^{1}$, David Quinn², Robert Dreicer ${ }^{3}$, Emmanuel Antonarakis ${ }^{4}$, Neal Shore ${ }^{5}$, John Corman ${ }^{6}$, \\ Raoul Concepcion ${ }^{7}$, Christopher Pieczonka ${ }^{8}$, Dwayne Campogann ${ }^{9}$, Li-Qun Fan ${ }^{9}$, Nancy Chang ${ }^{9 *}$, Nadeem Sheikh ${ }^{9}$, \\ Daniel Petrylak ${ }^{10}$
}

From 30th Annual Meeting and Associated Programs of the Society for Immunotherapy of Cancer (SITC 2015) National Harbor, MD, USA. 4-8 November 2015

\section{Background}

P12-2 (STRIDE; NCT01981122) is an ongoing, randomized, Phase II, open-label study evaluating concurrent vs sequential administration of the androgen receptor inhibitor, enz, with the autologous cellular immunotherapy, sip- $\mathrm{T}$. The primary aim of this study is to determine if the order of sip- $\mathrm{T}$ and enz administration impacts immune responses to the immunizing antigen, PA2024, of sip-T.

\section{Methods}

Patients with asymptomatic or minimally symptomatic mCRPC were randomized 1:1 to receive 3 sip- $\mathrm{T}$ infusions with enz starting 2 weeks (wks) before $(n=25$, concurrent arm A) or 10 wks after $(n=27$, sequential arm B) sip-T initiation. Antigen-specific cellular and humoral immune responses were evaluated via interferon (IFN) $\gamma$ ELISPOT, cell proliferation, and antibody ELISA assays. In addition, the breadth of the humoral response to non-target antigens was also studied.

\section{Results}

$\mathrm{T}$ cell proliferative responses to PA2024 were significantly elevated at all post-baseline time points $(\mathrm{p}<$ 0.001 ) and were sustained through wk 26 , including a $>10$-fold increase at wk 20 in both arms. Both arms showed a significant and sustained increase in IFN- $\gamma$

${ }^{9}$ Dendreon, Seattle, WA, USA

Full list of author information is available at the end of the article
ELISPOT response to PA2024 and humoral responses to PA2024 and PAP. Broadening of the humoral responses to non-target antigens PSA, LGALS3, LGALS8, KRAS, ERAS and KLK2 at all post-treatment time points was observed in both arms. Cytokines indicative of immune activation (including IFN- $\gamma$, interleukin-2, and tumor necrosis factor- $\alpha$ ) were also elevated in both arms, at the $2^{\text {nd }}$ and $3^{\text {rd }}$ sip- $T$ infusions. Adverse events were similar between arms.

\section{Conclusions}

Treatment of mCRPC subjects with enz administered concurrently with or subsequent to sip- $\mathrm{T}$ resulted in significant and sustained peripheral antigen-specific $T$ cell and humoral immune responses through wk 26. Both treatment schedules led to similarly robust humoral antigen spread sustained through wk 26. These data suggest enz did not affect sip-T production, subsequent immune responses, or safety.

Trial registration

ClinicalTrials.gov identifier NCT01981122.

\section{Authors' details}

'Department of Oncology, Sidney Kimmel Comprehensive Cancer Center at Johns Hopkins University, Baltimore, MD, USA. ${ }^{2}$ Norris Comprehensive Cancer Center, University of Southern California, Los Angeles, CA, USA. ${ }^{3}$ University of Virginia Cancer Center, Charlottesville, VA, USA. ${ }^{4}$ Johns Hopkins University School of Medicine, Baltimore, MD, USA. ${ }^{5}$ Atlantic Urology Clinics, Myrtle 
Beach, SC, USA. ${ }^{6}$ Virginia Mason Cancer Institute, Seattle, WA, USA. "Urology Associates, Nashville, TN, USA. ${ }^{8}$ Associated Medical Professionals of New York, Syracuse, NY, USA. ${ }^{9}$ Dendreon, Seattle, WA, USA. ${ }^{10}$ Yale Cancer Center, New Haven, CT, USA.

Published: 4 November 2015

doi:10.1186/2051-1426-3-S2-P145

Cite this article as: Drake et al: Immune response from STRIDE, a randomized, Phase II, open-label study of sipuleucel-T (sip-T) with concurrent vs sequential enzalutamide (enz) administration in metastatic castration-resistant prostate cancer (mCRPC). Journal for ImmunoTherapy of Cancer 2015 3(Suppl 2):P145.

Submit your next manuscript to BioMed Central and take full advantage of:

- Convenient online submission

- Thorough peer review

- No space constraints or color figure charges

- Immediate publication on acceptance

- Inclusion in PubMed, CAS, Scopus and Google Scholar

- Research which is freely available for redistribution

Submit your manuscript at www.biomedcentral.com/submit
() Biomed Central 